\title{
RANCANG BANGUN SISTEM PENGELOLAAN HAK KEKAYAAN INTELEKTUAL BERBASIS WEB PADA UNIVERSITAS RAHARJA
}

\author{
I. Handayani ${ }^{1)}$, N. Lutfiani'2), C. Y. Kristanti ${ }^{3)}$ \\ 1 Sains dan Teknologi, Universitas Raharja \\ 2 Sains dan Teknologi, Universitas Raharja \\ 3 Sains dan Teknologi, Universitas Raharja \\ Email: indri@raharja.info, ninda@raharja.info, citra.yulian@raharja.info
}

\begin{abstract}
ABSTRAK
Hak Kekayaan Intelektual atau biasa disebut dengan HKI adalah Hak ekonomis yang dimiliki oleh seseorang bagi hasil pemikirannya yang berbentuk produk ataupun proses yang berguna bagi manusia. Pengelolaan serta pemanfaatan HKI saat ini masih dirasa kurang maksimal, informasi terkait HKI belum tersampaikan kepada masyarakat luas. Perguruan Tinggi memiliki kewajiban untuk mengelola serta memanfaatkan hasil kegiatan dan inovasinya yang kemudian hasil tersebut wajib untuk disebarluaskan. Sistem Pengelolaan Hak Kekayaan Intelektual sangatlah penting bagi Perguruan Tinggi dalam mengelola serta menyebarluaskan informasi terkait HKI. Namun, saat ini sistem pengelolaan HKI yang ada di Universitas Raharja masih bersifat manual sehingga penyebarluasan informasi terkait HKI masih belum dapat dilakukan. Dari permasalahan tersebut maka diperlukan adanya sebuah Sistem Pengelolaan Hak Kekayaan Intelektual Berbasis Web supaya dapat mengelola sekaligus menyebarluaskan informasi terkait HKI yang diakses secara online sehingga informasi didapatkan dimana saja dan kapan saja. Penelitian ini menggunakan metode analisis SWOT dan menggunakan Content Management System (CMS).
\end{abstract}

Kata kunci: Sistem Pengelolaan, Hak Kekayaan Intelektual, Website

\begin{abstract}
Intellectual Property Rights or commonly referred to as IPR is an economic right owned by a person for the results of his thought in the form of products or processes that are useful to humans. The management and utilization of IPR is still not optimal, information on IPR has not been conveyed to the wider community. Higher Education has an obligation to manage and utilize the results of its activities and innovations which then the results must be disseminated. Intellectual Property Rights Management System is very important for Higher Education in managing and disseminating information related to IPR. However, the current IPR management system at Raharja University is still manual, so information dissemination related to IPR is still not possible. From these problems it is necessary to have a Web-Based Intellectual Property Management System in order to manage and disseminate information related to IPR that is accessed online so that information is obtained anywhere and anytime. This study uses a SWOT analysis method and uses a Content Management System (CMS).
\end{abstract}

Keywords : Management System, Intellectual Property Rights, Website

\section{PENDAHULUAN (STYLE: JPTK - HEADING 1)}

Hak Kekayaan Intelektual atau disingkat "HKI" ialah hak yang diperoleh secara eksklusif atas hasil olah pikir yang menghasilkan sesuatu baik berupa produk ataupun proses yang bermanfaat bagi manusia[1]. Indonesia telah mengenal HKI sejak Pemerintahan Kolonial Belanda yaitu pada tahun 1844 . Selain itu, Indonesia telah menjadi anggota Paris Convention for the Protection of Industrial Property sejak tahun 1888 dan anggota Berne Convention for the Protection of Literary and Aristic Works sejak tahun 1914. HKI penting untuk melindungi hasil karya dari perbuatan yang tidak diinginkan seperti menjiplak hasil karya. Selain itu, Hasil karya pun akan dihargai oleh orang lain dengan adanya HKI. Namun hingga saat ini masih banyak masyarakat yang belum mengerti akan pentingnya keberadaan $\mathrm{HKI}$. 
Perguruan Tinggi memegang peran penting sebagai institusi pendidikan dan pengajaran, serta Penelitian dan Pengabdian Pada Masyarakat yang memiliki fungsi untuk meningkatkan nilai tambah peserta didik supaya dapat menghasilkan kekayaan intelektual dari peserta didik yang sudah terlatih dan terdidik sebelumnya. Peran aktif Perguruan Tinggi juga dibutuhkan untuk memfasilitasi proses pengelolaan serta perolehan HKI yang dimiliki oleh Perguruan Tinggi tersebut.

Sesuai dengan Undang-Undang Nomor 18 Tahun 2002 tentang Sistem Nasional Penelitian, Pengembangan dan Penerapan Teknologi (UU Sisnas Litbangrap Iptek) yang menyatakan bahwa Perguruan Tinggi memiliki kewajiban untuk mengelola dan memanfaatkan hasil kegiatan dan inovasinya. Kemudian hasil kegiatan dan inovasi yang sudah dikelola lalu wajib disebarluaskan. Selain itu, Perguruan Tinggi juga perlu memiliki suatu institusi yang khusus untuk melakukan pengelolaan kekayaan intelektual sebagai pengelola sekaligus media penyebarluasan informasi mengenai hasilhasil kegiatan penelitian yang sudah dilakukan.Sentra HKI yang wajib dibentuk nantinya diharapkan dapat berfungsi untuk mengelola dan memanfaatkan kekayaan intelektual yang dimiliki oleh Perguruan Tinggi sekaligus sebagai pusat informasi dan pelayanan HKI termasuk pendaftarannya.

Saat ini Universitas Raharja masih menggunakan sistem pengelolaan Hak Kekayaan Intelektual secara konvensional dimana ketika akan dilakukan rekapitulasi jumlah hasil kekayaan intelektual setiap periodenya bagian operator pengelola harus menghubungi para dosen satu persatu dan menanyakan apakah dosen tersebut telah menghasilkan kekayaan intelektual atau belum pada periode tersebut.

Sistem yang berjalan saat ini sangatlah kurang efisien dalam segi waktu. Dimana kegiatan yang dilakukan operator untuk menghubungi satu persatu dosen akan menghabiskan waktu yang cukup lama. Selain itu operator juga harus melakukan rekapitulasi data jumlah dosen atau pun mahasiswa yang telah menghasilkan kekayaan intelektual sebagai bukti hasil kinerja penelitian pada Universitas.

Dengan adanya kekurangan tersebut, diperlukan sebuah sistem yang akan memudahkan tugas operator dalam mengelola Hak Kekayaan Intelektual. Sistem tersebut adalah Sistem Pengelolaan Hak Kekayaan Intelektual Berbasis Web. Tujuan diadakannya Sistem Pengelolaan Hak Kekayaan Intelektual Berbasis Web adalah memudahkan operator dalam melaksanakan tugasnya melakukan rekapitulasi kekayaan intelektual. Sistem ini dibuat berbasis Web agar mudah diakses kapan saja dan dimana saja tidak terikat tempat dan waktu.

Website Pengelolaan Hak Kekayaaan Intelektual Pada Universitas Raharja, merupakan suatu sistem pengelolaan Hak Kekayaan Intelektual yang akan merekap sekaligus memaparkan Hak Kekayaan Intelektual yang dimiliki oleh civitas akademika Universitas Raharja yang dapat diakses secara online. Yang bertujuan untuk mempermudah dalam pengelolaan kekayaan intelektual yang dimiliki oleh para civitas akademika Universitas Raharja.

Dengan adanya Website Pengelolaan Hak Kekayaaan Intelektual Pada Universitas Raharja ini sangat membantu pekerjaan operator serta membantu Pribadi Raharja yang memiliki kekayaan intelektual karena pada website ini akan menampilkan hasil Kekayaan Intelektual sehingga kekayaan intelektual tersebut dapat memberikan manfaat bagi masyarakat luas yang melihatnya.

Selain itu Website ini juga dapat digunakan sebagai media pendaftaran Hak Kekayaan Intelektual yang dimiliki oleh Pribadi Raharja. Sehingga hasil Kekayaan Intelektual para Pribadi Raharja akan terhindar dari perbuatan yang tidak terpuji seperti "Penjiplakan". Dan Hasil Kekayaan Intelektual yang dimiliki juga dapat lebih bermanfaat karena memiliki nilai ekonomis.

\section{METODE}

Dalam penelitian kali ini menerapkan beberapa metode penelitian yaitu Metode analisis SWOT dan Metode Studi Pustaka.

\section{A. Metode Analisis SWOT}

Metode Analisis SWOT merupakan suatu metode analisa yang dapat memperoleh gambaran menyeluruh akan situasi dan kinerja perusahaan yang didasarkan pada logika.

Tabel 1. Analisis SWOT

\begin{tabular}{|c|c|c|c|}
\hline & Strengths (S) & & Weakness (W) \\
\hline 1. & $\begin{array}{ll}\text { Perguruan } & \text { Tinggi } \\
\text { berkonsentrasi } & \text { dibidang } \\
\text { dan informasi } & \end{array}$ & $\begin{array}{r}\text { Raharja } \\
\text { teknologi }\end{array}$ & $\begin{array}{l}\text { 1. Sitem tidak dapat manampilkan } \\
\text { data HKI } \\
\text { 2. Sistem pengelolaan HKI bersifat }\end{array}$ \\
\hline
\end{tabular}




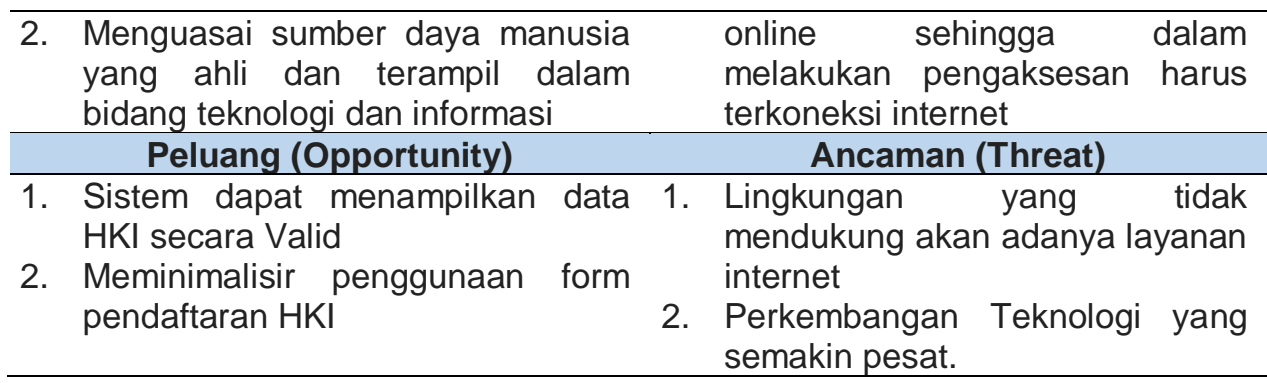

Tabel 2. Matriks SWOT

\begin{tabular}{|c|c|c|}
\hline Eksternal & $\begin{array}{c}\text { Strength (S) } \\
\text { Kekuatan }\end{array}$ & $\begin{array}{c}\text { Weakness (W) } \\
\text { Kelemahan }\end{array}$ \\
\hline \multirow{3}{*}{$\begin{array}{c}\text { Opportunities (0) } \\
\text { Peluang }\end{array}$} & SO & WO \\
\hline & $\begin{array}{l}\text { Dengan memanfaatkan } \\
\text { teknologi yang ada pada } \\
\text { Universitas Raharja } \\
\text { membuat sistem yang } \\
\text { dapat mengelola Hak } \\
\text { Kekayaan Intelektual }\end{array}$ & $\begin{array}{l}\text { 1. Menciptakan sistem } \\
\text { yang dapat } \\
\text { menampilkan data } \\
\text { Hak Kekayaan } \\
\text { Intelektual recara } \\
\text { Valid }\end{array}$ \\
\hline & $\begin{array}{l}\text { 2. Dengan adanya sumber } \\
\text { daya manusia yang ahli } \\
\text { dan terampil dalam } \\
\text { bidang teknologi sehigga } \\
\text { dapat menunjang } \\
\text { pengembangan sistem } \\
\text { Hak Kekayaan } \\
\text { Intelektual sehingga tidak } \\
\text { terjadi kesenjangan } \\
\text { dalam pengelolaan Hak } \\
\text { Kekayaan Intelektual } \\
\end{array}$ & \\
\hline \multirow{2}{*}{$\begin{array}{c}\text { Threats }(T) \\
\text { Ancaman }\end{array}$} & ST & WT \\
\hline & $\begin{array}{l}\text { 1. Memanfatkan sumber } \\
\text { daya manusia yang } \\
\text { berkompeten sehingga } \\
\text { dapat mengembangkan } \\
\text { sistem sehingga dapat } \\
\text { mengikuti perkembangan } \\
\text { teknologi yang terus } \\
\text { berjalan }\end{array}$ & $\begin{array}{l}\text { 2. Membuat sistem } \\
\text { pengelolaan secara } \\
\text { online sehingga } \\
\text { dapat dikembangkan } \\
\text { mengikuti } \\
\text { perkembangan } \\
\text { teknologi yang ada }\end{array}$ \\
\hline
\end{tabular}

Berdasarkan penjelasan yang sudah dijabarkan dapat disimpulkan bahwa, dengan menggunakan metode analisis SWOT dapat dilihat perbandingan antara kekuatan, kelemahan, peluang serta ancaman yang akan timbul pada sistem pengelolaan Hak Kekayaan Intelektual (HKI). Pada pengelolaan yang sekarang dapat lebih terdistribusi dengan baik dan dapat memangkas waktu beserta biaya yang akan dikeluarkan, sehingga banyaknya minat dalam pendaftaran Hak Kekayaan Intelektual. 


\section{B. Metode Content Management System (CMS)}

Metode Content Management System (CMS) atau Sistem Manajemen Konten ini digunakan dalam perancangan sistem pengelolaan Hak Kekayaan Intelektual guna dapat menampilkan data Hak Kekaayaan Intelektual sehingga penyebaran informasi terkait Hak Kekayaan Intelektual pada Universitas Raharja menjadi lebih baik.

Pada perancangan Sistem Pengelolaan Hak Kekayaan Intellektual ini menggunakan salah satu perangkat lunak yang dimiliki oleh Content Management System (CMS) yaitu Wordpress. Dengan karakter Open Source yang dimiliki oleh Wordpress sehingga mudah untuk didapat. Selain itu keunggulan dari Wordpress ini sendiiri adalah kemudahannya dalam penyesuaian serta modifikasi sehingga sesuai dengan kebutuhan pengguna.

\section{Metode Studi Pustaka}

Dalam upaya meningkatkan Sistem Pengelolaan Hak Kekayaan Intelektual sebagai media pengelola serta pemanfaatan Hak Kekayaan Intelektual, terdapat beberapa literature review yang sudah dipahami untuk mengurangi kesenjangan, menghindari pengulangan, serta meneruskan penelitian yang sudah ada sebelumnya. Berikut adalah 10 (sepuluh) referensi literature review, diantaranya yaitu :

a. Penelitian yang telah dilakukan oleh Driantama Edya Nugraha, Tri Sagirani dan Julianto Lemantara (2019), dengan judul "Rancang Bangun Aplikasi Pengelolaan Hak Kekayaan Intelektual Berbasis Web (Studi Kasus Sentra HKI Universitas Muhammadiyah Surabaya)"[2]. Penelitian ini membahas tentang kendala dari sistem yang berjalan pada Sentra HKI Universitas Muhammadiyah Surabaya saat ini yaitu antara lain aplikasi proses masih dilakukan secara manual, tidak ada riwayat yang dikirimkan, dan tidak ada proses. Aplikasi Manajemen dapat menjadi solusi dari masalah ini. Dengan adanya Aplikasi Manajemen ini pendaftar dapat melakukan permintaan kapanpun dan dimanapun, adanya riwayat pendaftaran, serta adanya proses penilaian dengan poin yang telah diperoleh dari perhitungan menggunakan Analytical Metode Hierarchy Process (AHP).

b. Penelitian yang telah dilakukan oleh Wahyudin Darmalaksana (2017), yang berjudul "Permohonan Hak Cipta Atas Kekayaan Intelektual Berbasis Elektronik"[3]. Dalam penelitiannya ini membahas tentang permohonan hak cipta atas kekayaan intelektual yang dilakukan secara elektronik. Sebelum permohonan secara elektronik, terlebih dahulu Perguruan Tinggi mendirikan Sentra HKI/Paten serta melakukan registrasi pada Direktorat Jenderal Kekayaan Intelektual Kementerian Hukum dan Hak Asasi Manusia Republik Indonesia.

c. Penelitian ini dilakukan oleh Mieke Yustia Ayu Ratna Sari (2016), dengan judul "Pembangunan Kekayaan Intelektual (KI) Berbasis Teknologi Informasi Di Era Global"[4]. Penelitian ini membahas tentang peran teknologi yang sangat besar dapat dimanfaatkan secara maksimal dalam kegiatan pembangunan kekayaan intelektual. Keberadaan kekayaan intelektual memiliki pengaruh yang besar karena dapat mendorong sektor perekonomian masyarakat serta dapat menunjang kesejahteraan warga. Dengan adanya perkembangan Teknologi Informasi dapat membantu proses permohonan pendaftaran serta publikasi kekayaan intelektual. Direktorat Jenderal Kekayaan Intelektual telah mengembangkan sistem pendaftaran menjadi berbentuk "e-filling" serta publikasi layanan data dan informasi yang ada pada bidang kekayaan intelektual. Sebagai media penyampaian informasi terkait pengajuan kekayaan intelektual.

d. Penelitian yang telah dilakukan oleh Neni Sri Imaniyati (2015), dengan judul "Perlindungan HKI Sebagai Upaya Pemenuhan Hak Atas IPTEK, Budaya dan Seni"[5]. Penelitian ini membahas tentang keadaan Indonesia yang belum dapat menerapkan TRIPs karena adanya pandangan negatif terhadap HKI. Pandangan tersebut yaitu adanya keraguan atas kemungkinan kerugian yang akan ditimbulkan apabila penerapan HKI dilakukan di Indonesia. Kemungkinan tersebut berkaitan dengan tingginya biaya yang akan timbul, tidak adanya pengaruh yang signifikan terhadap masuknya penanaman modal asing ke Indonesia, serta kemungkinan akan adanya "pembajakan biologis" terhadap sumber daya alam Indonesia. Perlu adanya kerjasama antara Pemerintah dengan Perguruan Tinggi dalam menegakkan dan mendorong pendirian atas institusi (semacam sentra HKI), dalam melaksanakan fungsi advokasi yang akan membantu inventor dan kreator dalam melakukan proses pendaftaran $\mathrm{HKI}$ sehingga dapat memudahkan masyarakat untuk mendaftarkan HKI. 
e. Penelitian yang telah dilakukan oleh Derta Rahmanto dan Endang Purwaningsih (2017), yang berjudul "Pengetahuan Hak Kekayaan Intelektual (HKI) Dosen Dalam Upaya Meningkatkan Kesadaran Ber-HKI Civitas Academica"[6]. Dalam penelitiannya ini membahas bahwa Karya intelektual lahir dari hasil cipta rasa karsa civitas academica. Dalam upaya meningkatkan kesadaran memiliki HKI bagi dosen Universitas YARSI yaitu dengan cara menambahkan wawasan serta pengetahuan terkait HKI. Selain itu, dapat pula memberikan penghargaan bagi para dosen yang telah berhasil dalam publikasi ilmiah dan pendaftaran paten.

f. Penelitian ini dilakukan oleh Andri Cahyono, Bayu Pramono dan Fitra Putri Oganda (2019), dengan judul "Design of Information System in Admission of New Students Based on Web in SMK Al Amanah"[7]. Penelitian ini membahas tentang sistem penerimaan siswa baru di Sekolah Kejuruan Al Amanah Pasar Kemis dengan berbasis web sehingga dapat mempermudah calon mahasiswa dalam melakukan pendaftaran serta mendapatkan informasi seputar pendaftaran calon siswa baru. Pada pemrosesan data penerimaan siswa baru sebelumnya masih menggunakan masih menggunakan sistem konvensional dengan mendatangi langsung sekolah dan mengisikan formulir. Sistem tersebut membutuhkan waktu yang sangat lama serta dapat mengakibatkan kerugian kearsipan. Sistem informasi penerimaan siswa baru ini berbasis web dengan tujuan dapat mendapatkan kenyamanan bagi orang tua siswa baru karena semua informasi bisa didapatkan secara online.

g. Penelitian yang telah dilakukan oleh Qurotul Aini, Untung Rahardja dan Femi Allamiah (2018), dengan judul "Perancangan Sistem Absensi Kinerja Pengabdian Tri Dharma secara Online pada Website Berbasis YII Framework"[8]. Penelitian ini membahas tentang perkembangan teknologi yang semakin canggih dan sangat mudah untuk diakses, sehingga semua kebutuhan hidup manusia dapat diakses secara online. Saat ini masih belum banyak sistem absensi yang dapat dengan mudah diakses secara online dan masih sering terjadi penitipan absensi dengan teman sesama yang menjalani Pengabdian Tri Dharma. Maka dari itu membutuhkan sebuah perkembangan dalam sistem yang berjalan ini. Dengan adanya perancangan sebuah sistem absensi untuk kinerja Pengabdian Tri Dharma yang dapat diakses secara online, dapat mencegah terjadinya kecurangan pada kegiatan absensi. Sistem absensi ini dapat dengan mudah dilakukan hanya dengan cara Scan QR code.

h. Penelitian yang telah dilakukan oleh Rano Kurniawan, Muhamad Zahruddin dan Mira Shintia (2019), yang berjudul "Perancangan Sistem Informasi Korespondensi Berbasis Website Pada Kantor Pertanahan Kota Tangerang"[9]. Dalam penelitiannya ini membahas tentang Sistem korespondensi yang ada pada Kantor Pertanahan Kota Tangerang. Sistem korespondensi yang saat ini berjalan pada kantor pertanahan kota Tangerang masih secara manual. Terutama pada surat masuk yang masih belum dapat terintegrasi dan terkomputerisasi dalam hal penyimpanan, penginputan, pencarian, serta pencetakan lembar disposisi dan laporan setiap bulannya. Hal ini tentu saja dapat berakibat pada proses penginputan dan pelaporan yang memakan waktu relatif lama. Maka dengan adanya penelitian ini dibuatlah sebuah perancangan sistem informasi korespondensi yang ada pada kantor pertanahan kota Tangerang. Hasil dari penelitian ini diharapkan dapat mengurangi terjadinya kesalahan pada saat proses pendataan, penyimpanan, pencarian data serta pembuatan laporan dan juga lebih efisien karena tidak menghabiskan waktu yang lama.

i. Penelitian ini dilakukan oleh Nurlaila Suci Rahayu Rais, Ruli Supriati dan Siti Ika Danti (2018), dengan judul "Instalasi Open Journal System (OJS) Versi 3 Sebagai Pendukung Kegiatan Pengelolaan dan Publikasi Jurnal IImiah"[10]. Penelitian ini membahas tentang Open Journal System (OJS). Penelitian ini memahami bagaimana cara untuk instalasi OJS versi 3 serta untuk mengetahui apa saja kelebihan OJS versi 3.

j. Penelitian yang telah dilakukan oleh Al Husain, Wildan Muhtadin dan Agus Supriadi (2018), dengan judul "Perancangan Sistem Informasi Pengingat Perbaikan Komponen Pesawat Berbasis Web"[11]. Penelitian ini membahas tentang aplikasi Perancangan Sistem Informasi Pengingat Perbaikan Komponen Pesawat yang akan diajukan pada PT. GMF Aeroasia. Sistem Informasi Pengingat Perbaikan Komponen Pesawat yang akan diajukan yaitu menggunakan SMS Gateway. SMS Gateway ini akan berfungsi sebagai pengingat (reminder) dan juga autorespond.

Dari beberapa literature review yang sudah dipelajari diatas, dapat ditarik kesimpulan bahwa banyak penelitian yang telah dilakukan terkait pentingnya sistem pengelolaan sehingga dapat dijadikan sebagai media untuk mengelola serta memanfaatkan kekayaan intelektual milik seseorang. 


\section{HASIL DAN PEMBAHASAN}

Dengan adanya perkembangan teknologi saat ini pada industri 4.0, pemanfaatan teknologi tidaklah begitu rumit, terutama dalam bidang pendidikan. Dalam berbagai informasi yang telah didapatkan bahwa telah banyak sistem pengelolaan yang sudah berbasis web. Pada sistem pengelolaan Hak Kekayaan Intelektual sebelumnya dapat merekap data hasil perolehan kekayaan intelektual secara manual dan belum dapat menyebarkan informasi terkait kekayaan intelektual. Sedangkan pada sistem pengelolaan kekayaan intelektual ini kegiatan perekapan data sudah secara online, penyebaran informasi sudah dapat dilakukan, selain itu juga dapat melakukan pendaftaran atas kekayaan intelektual yang dimiliki.

Dari permasalahan yang terdapat diatas penulis berniat untuk mengembangkan sistem pengelolaan hak kekayaan intelektual yang sudah ada di Universitas Raharja yang kemudian nantinya akan diterapkan pada Universitas Raharja. Sistem Pengelolaan Hak Kekayaan Intelektual Berbasis Web merupakan salah satu sistem yang ada pada Universitas Raharja yang memiliki beberapa kelebihan dibandingkan sistem pengelolaan hak kekayaan intelektual sebelumnya. Sistem ini nantinya dapat diakses secara online dimana saja dan kapan saja sehingga sangat memudahkan para pribadi Raharja.

Setelah diadakannya penelitian terhadap permasalahan yang ada, Sistem Pengelolaan Hak Kekayaan Intelektual untuk yang sebelumnya masih menggunakan cara konvensional atau manual. Sehingga untuk proses pengelolaan kekayaan intelektual yang berjalan saat ini masih membutuhkan waktu yang sangat lama. Sistem pengelolaan Hak Kekayaan Intelektual tentunya dibuat untuk memudahkan operator dalam melakukan pengelolaan sehingga dapat menjadi lebih efektif dan efisien

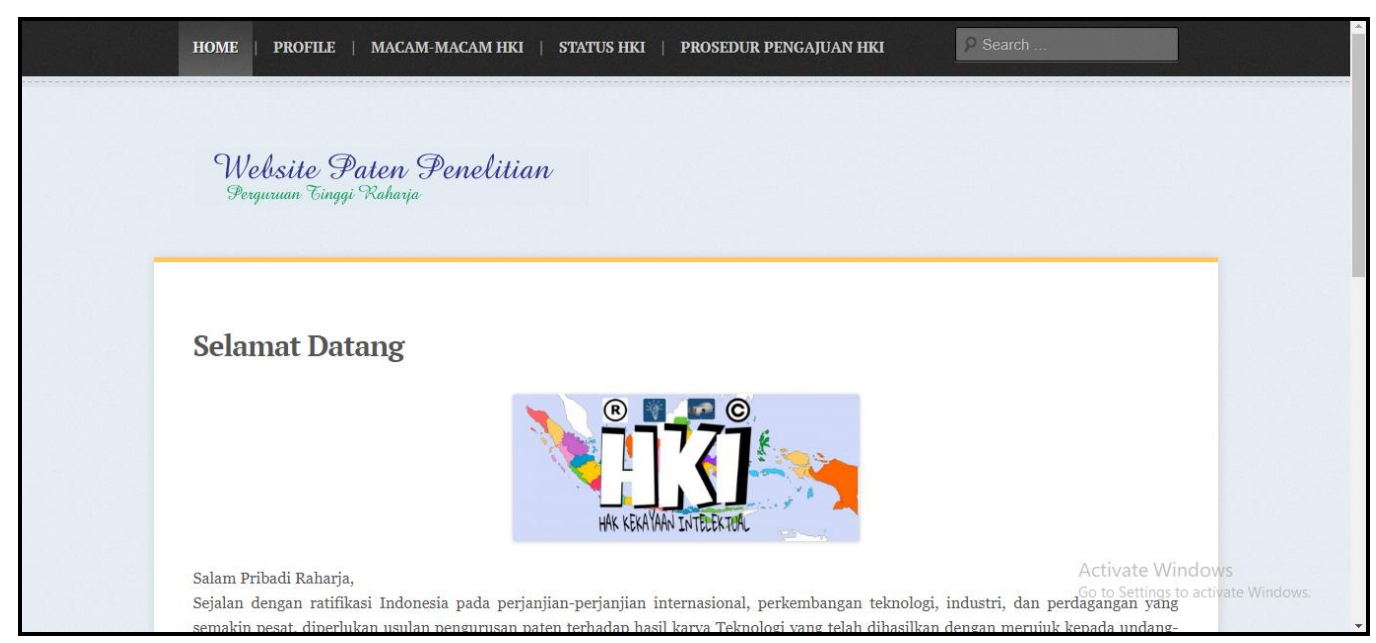

Gambar 1. Tampilan Awal website HKI

Gambar diatas merupakan tampilan awal atau home pada website HKI. Tampilan awal ini memuat tentang logo dan sambutan dari Ketua REC (Raharja Enrichment Centre). Sambutan tersebut sebagai penjelasan latar belakang pada pendirian pengelola HKI tersebut. Sedangkan REC (Raharja Enrichment Centre) merupakan lembaga penelitian dan pengabdian masyarakat yang ada di Universitas Raharja. 


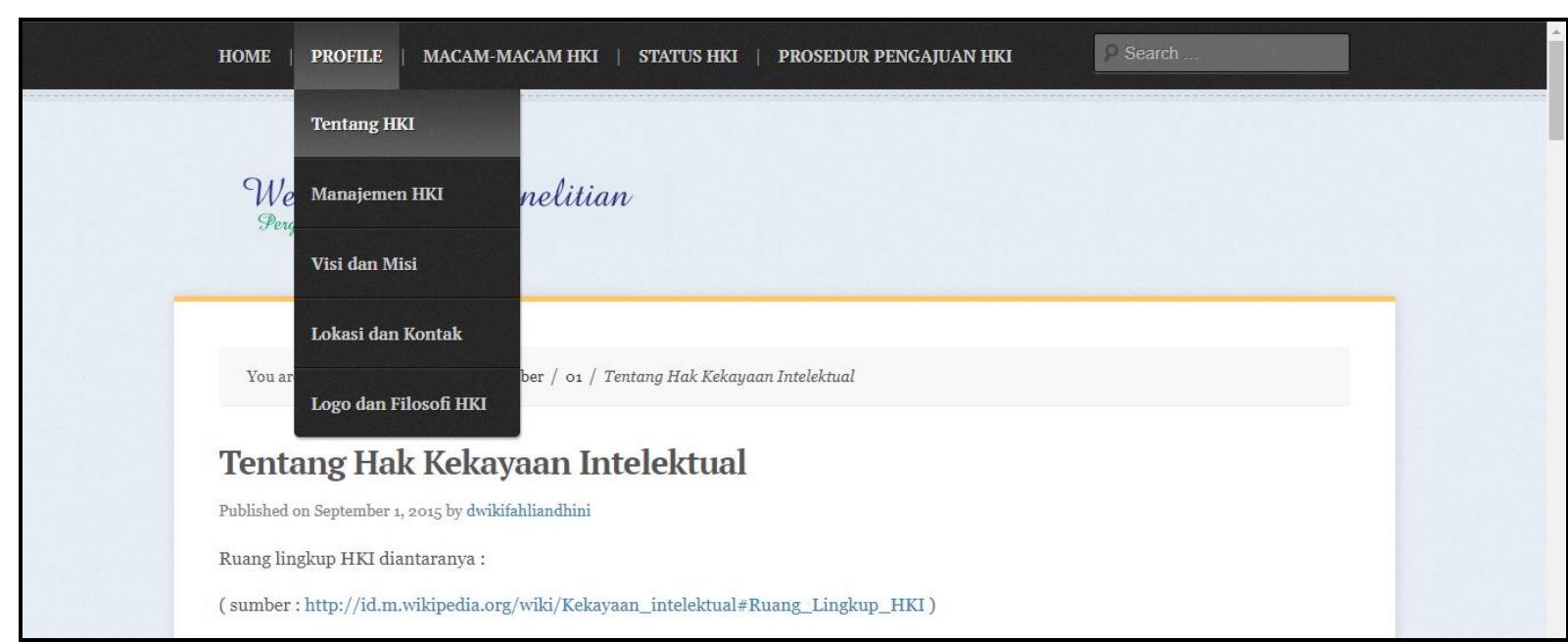

Gambar 2. Tampilan Halaman Tentang HKI

Gambar kedua merupakan salah satu halaman yang ada pada menu Profile. Menu Profile berisi beberapa submenu yaitu Tentang HKI, Manajemen HKI, Visi dan Misi HKI, Lokasi dan Kontak, Logo dan Filosofi HKI. Submenu Tentang HKI berisi tentang ruang lingkup yang ada dalam HKI serta Undang - Undang yang mengatur tentang HKI. Submenu Manajemen HKI berisi tentang struktur organisasi HKI yang berlaku. Submenu Visi dan Misi berisi Visi HKI Universitas Raharja yaitu Menjadikan HKI Universitas Raharja sebagai pusat pelayanan suatu karya agar mendapatkan sertifikasi dengan mudah dan terpercaya, serta Misi HKI Universitas Raharja yaitu Melayani dengan sepenuh hati untuk memperoleh informasi berbagai hal mengenai HKI di Universitas Raharja, Bekerja secara profesional agar membuat customer menjadi puas atas pelayanan kami, Memudahkan dalam proses pengajuan suatu karya. Submenu Lokasi dan Kontak berisi tentang Lokasi Universitas Raharja serta Kontak yang dapat dihubungi. Submenu Logo dan Filosofi HKI memuat tentang Logo HKI serta Filosofi dari Logo HKI tersebut.

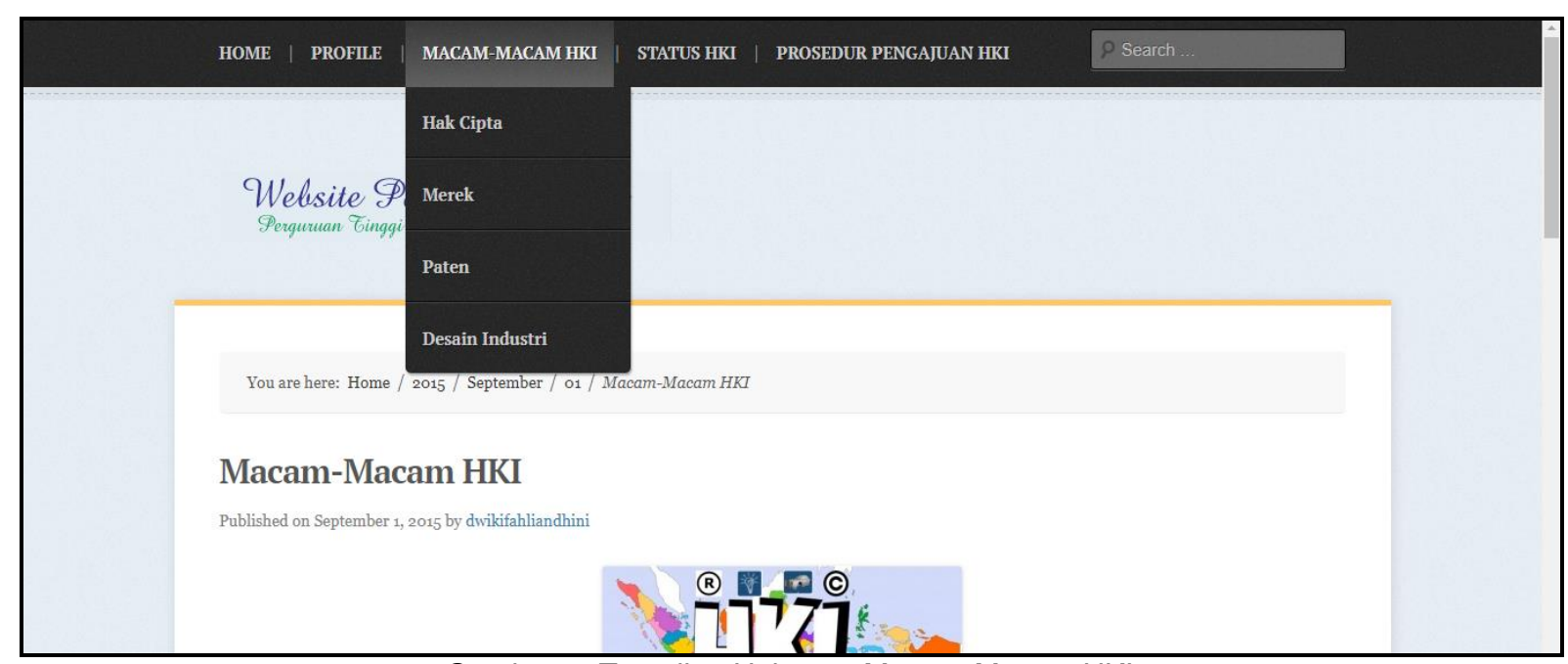

Gambar 3. Tampilan Halaman Macam-Macam HKI

Pada Gambar ketiga merupakan tampilan halaman dari menu Macam-Macam HKI. Dalam menu ini memiliki 4 submenu yaitu Hak Cipta, Merek, Paten dan Desain Industri. Pada masing masing submenu berisi tentang informasi terkait jenis HKI, mulai dari pengertian, undang - undang, formulir yang dibutuhkan untuk melakukan pendaftaran sampai dengan tarif untuk pendaftarannya. 


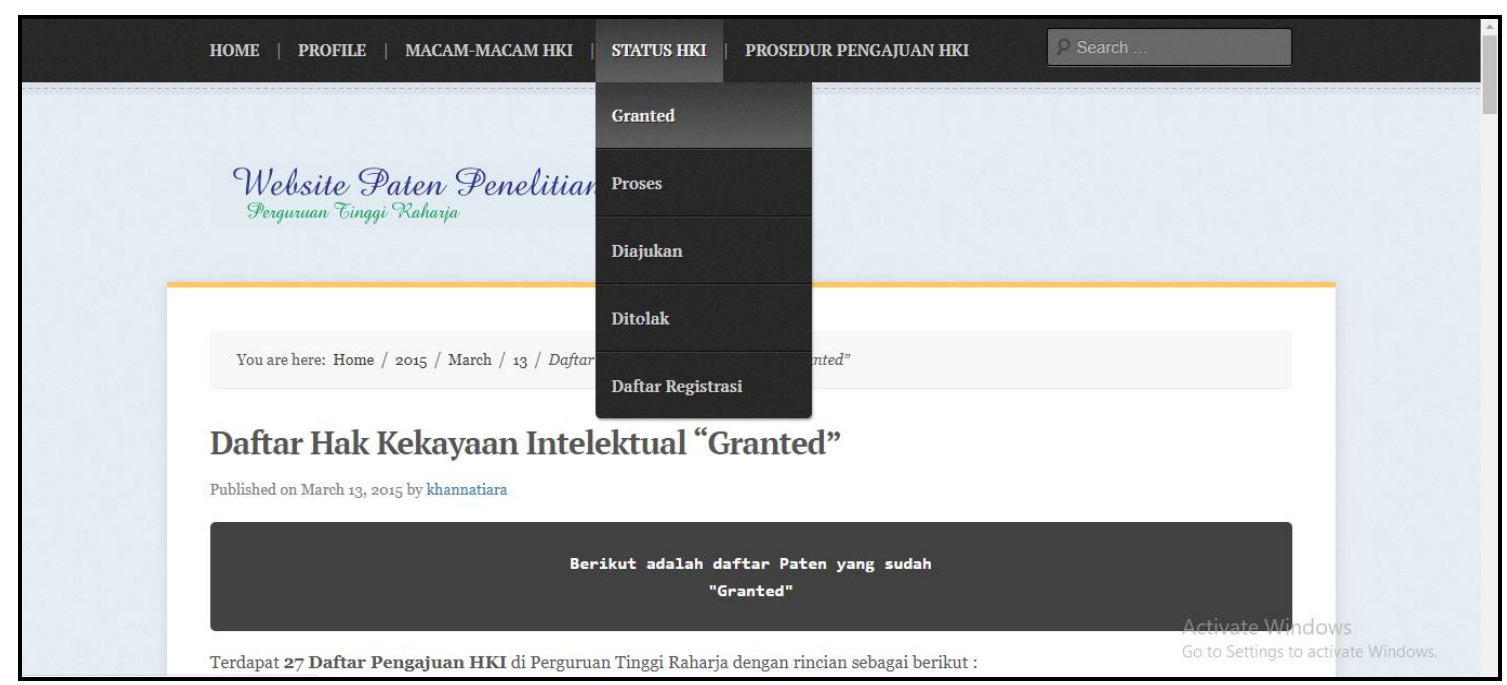

Gambar 4. Tampilan Halaman Granted

Gambar diatas merupakan tampilan dari salah satu submenu yang ada pada menu Status HKI yaitu Granted. Menu Status HKI terbagi menjadi beberapa submenu diantaranya yaitu Granted, Proses, Diajukan, Ditolak, Daftar Registrasi. Pada submenu Granted berisi daftar kekayaan intelektual yang sudah terdaftar dan diterima di Direktorat Jenderal kekayaan Intelektual. Submenu selanjutnya yaitu Proses berisi daftar kekayaan intelektual yang sudah diajukan ke DJKI namun sedang dalam Proses untuk diterima oleh DJKI. Submenu Diajukan berisi daftar kekayaan intelektual yang diajukan setiap tahunnya. Submenu yang selanjutnya yaitu Ditolak, pada submenu tersebut berisi daftar kekayaan intelektual yang sudah didaftarkan ke pihak DJKI namun tidak diterima oleh pihak DJKI. Submenu yang terakhir yaitu submenu Daftar Registrasi yang berisi daftar kekayaan intelektual yang sudah mendaftar pada website HKI Universitas Raharja dan belum didaftarkan pada pihak DJKI.

Saat ini terdapat 27 kekayaan intelektual yang sudah didaftarkan ke pihak DJKI dengan status 17 kekayaan intelektual yang diterima, 8 kekayaan intelektual yang ditolak dan 2 kekayaan intelektual yang sedang dalam proses. Selain itu juga terdapat 4 kekayaan intelektual yang sudah mendaftar pada Website HKI Universitas Raharja dan belum didaftarkan pada DJKI.

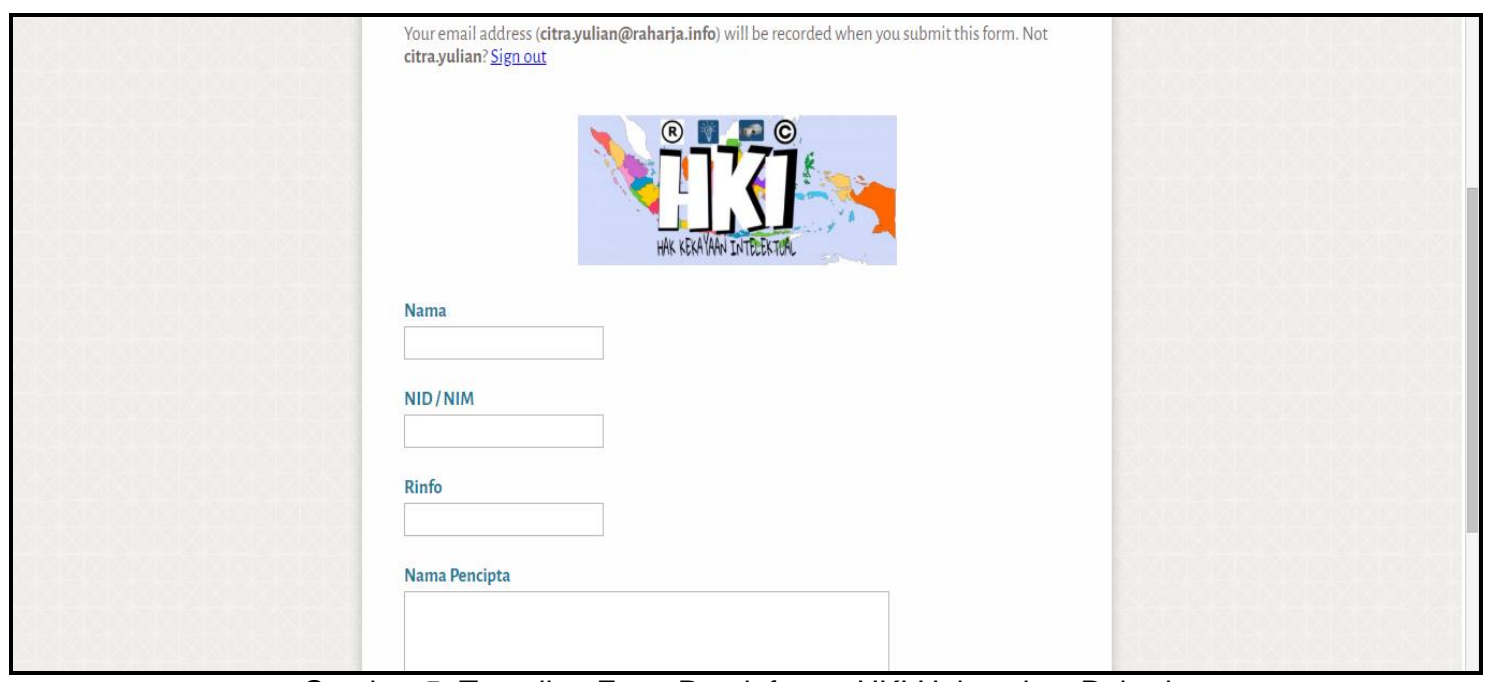

Gambar 5. Tampilan Form Pendaftaran HKI Universitas Raharja

Gambar diatas merupakan tampilan form untuk melakukan pendaftaran pada Website HKI Universitas Raharja. Form tersebut akan masuk pada email HKI Universitas Raharja yang dipegang oleh Operator HKI Universitas Raharja. Dari data yang sudah didapat dari form nantinya operator akan mencatatnya dan mendaftarkannya pada pihak DJKI. 


\section{SIMPULAN DAN SARAN}

Berdasar pada analisa yang sudah dilakukan oleh penulis pada Universitas Raharja, maka dapat ditarik beberapa kesimpulan dari pengembangan sistem Pengelolaan Hak Kekayaan Intelektual yaitu saat ini Universitas Raharja masih menggunakan sistem yang konvensional dimana untuk mendapatkan data pemilik kekayaan intelektual operator harus menghubungi dosen satu persatu dengan cara meneleponnya.

Dengan membangun Sistem Pengelolaan Hak Kekayaan Intelektual yang dapat berjalan dengan efektif dan efisien serta memberikan kemudahan bagi operator dalam melakukan pengelolaan data kekayaan intelektual. Dengan merubah sistem yang semula masih konvensional menjadi sebuah sistem yang berjalan online yang dapat diakses kapan saja dan dimana saja sehingga dapat mempermudah kerja operator.

Keberadaan sistem Pengelolaan Hak Kekayaan Intelektual yang berjalan saat ini masih memiliki banyak kekurangan. Tugas yang diemban oleh operator sangat banyak. Sistem yang berjalan saat ini pun belum dapat melakukan pendaftaran Hak Kekayaan Intelektual. Sehingga pribadi Raharja yang memiliki Kekayaan Intelektual harus mendaftarkannya sendiri ke pihak DJKI.

Adapun saran yang penulis dapat berikan sebagai acuan yang digunakan dalam meningkatkan sistem yang ada sehingga pada penelitian selanjutnya dapat mengembangkan sistem ini menjadi lebih baik lagi, sehingga kekurangan yang masih ada dapat teratasi adalah dengan mengembangkan Sistem Pengelolaan Hak Kekayaan Intelektual yang berjalan saat ini di Universitas Raharja sehingga meminimalisir kekurangan yang terdapat pada sistem yang berjalan saat ini.

Selain itu perlu diadakannya sosialisasi khususnya kepada pribadi Raharja sehingga para Pribadi Raharja dapat mengetahui sistem pengelolaan hak kekayaan intelektual yang akan diterapkan nantinya.

Dan yang terakhir perlu adanya perubahan dalam Sistem Pengelolaan Hak Kekayaan Intelektual yang berjalan saat ini. Seperti merubah cara yang tadinya manual menjadi terkomputerisasi. Dari sistem yang konvensional menjadi online menggunakan jaringan internet. Sehingga dapat diakses kapan saja dan dimana saja oleh Pribadi Raharja.

\section{UCAPAN TERIMAKASIH}

Peneliti ucapkan banyak terimakasih kepada para pihak yang telah berkontribusi dalam penyelesaian penelitian ini. Terutama kepada Tuhan Yang Maha Esa, yang telah memberikan berkat rahmat-Nya berupa kesehatan, kesempatan serta ilmu pengetahuan sehingga penelitian ini dapat terselesaikan. Dan juga mengucapkan terimakasih kepada penulis 1 dan penulis 2 atas partisipasinya sebagai pembimbing selama penelitian ini berjalan. Terimakasih juga kepada Universitas Raharja yang telah memberikan fasilitas dalam penelitian ini, dan kepada pengelola Hak Kekayaan Intelektual yang telah bersedia membantu dan memberi arahan nya kepada peneliti.

\section{DAFTAR PUSTAKA}

[1] Samsudin, D. (2016). Hak Kekayaan Intelektual dan Manfaatnya Bagi Lembaga Litbang. Jakarta:Direktorat Jenderal Kekayaan Intelektual Kementerian Hukum dan Hak Asasi Manusia..

[2] Nugraha, D. E., Sagirani, T., \& Lemantara, J. (2019). Rancang Bangun Aplikasi Pengelolaan Hak Kekayaan Intelektual Berbasis Web (Studi Kasus Sentra HKI Universitas Muhammadiyah Surabaya). Jurnal JSIKA, 8(1), 82-89.

[3] Darmalaksana, W. (2017). Permohonan Hak Cipta Atas Kekayaan Intelektual Berbasis Elektronik.

[4] Sari, M. Y. A. R. (2016). Pembangunan Kekayaan Intelektual (Ki) Berbasis Teknologi Informasi di Era Global.

[5] Imaniyati, N. S. (2015). Perlindungan HKI Sebagai Upaya Pemenuhan Hak Atas IPTEK, Budaya dan Seni. Media Hukum, 17(1).

[6] Purwaningsih, E. (2017). Pengetahuan Hak Kekayaan Intelektual (HKI) Dosen Dalam Upaya Meningkatkan Kesadaran Ber-HKI Civitas Academica. Jurnal surya kencana dua dinamika masalah hukum dan keadilan, 3(2). 
[7] Cahyono, A., Pramono, B., \& Oganda, F. P. (2019). Design of Information System in Admission of New Students Based on Web in SMK Al Amanah. Aptisi Transactions on Management (ATM), 3(2), 159-167.

[8] Aini, Q., Rahardja, U., \& Allamiah, F. (2018). Perancangan Sistem Absensi Kinerja Pengabdian Tri Dharma secara Online pada Website Berbasis YII Framework. Sisfotenika, 8(1), 13-22.

[9] Kurniawan, R., Zahruddin, M., \& Shintia, M. (2019). Perancangan Sistem Informasi Korespondensi Berbasis Website Pada Kantor Pertanahan Kota Tangerang. Technomedia Journal, 4(1), 30-43.

[10] Rais, N. S. R., Supriati, R., \& Danti, S. I. (2018). Instalasi Open Journal System (OJS) Versi 3 Sebagai Pendukung Kegiatan Pengelolaan dan Publikasi Jurnal IImiah. Technomedia Journal, 2(2), 66-80.

[11] Husain, A., Muhtadin, W., \& Supriadi, A. (2018). Perancangan Sistem Informasi Pengingat Perbaikan Komponen Pesawat Berbasis Web. Technomedia Journal, 2(2), 119-130. 